\title{
Length-weight relationship, sex ratio, mortality and growth condition of natural stock of Macrobrachium rosenbergii from the estuarine systems of North Kalimantan, Indonesia
}

\author{
AGUS INDARJO ${ }^{1, \bullet}$, GAZALI SALIM ${ }^{2}$, CHRISTINE DYTA NUGRAENI ${ }^{3}$, MUFRIDA ZEIN ${ }^{4}$, \\ JULIAN RANSANGAN ${ }^{5}$, LUKMAN YUDHO PRAKOSO ${ }^{6}$, SUHIRWAN ${ }^{6}$, SUTRISNO ANGGORO $^{7}$ \\ ${ }^{1}$ Department of Marine Science, Faculty of Fisheries and Marine Science, Universitas Diponegoro. Jl. Prof. H. Soedarto, S.H, Tembalang, Semarang \\ 50275, Central Java, Indonesia. Tel./fax.: +62-24-7474698, ^email: indarjoa@yahoo.com \\ ${ }^{2}$ Department of Aquatic Resource Management, Faculty of Fisheries and Marine Science, Universitas Borneo Tarakan. Jl. Amal Lama No. 1, Tarakan \\ 77115 , North Kalimantan, Indonesia \\ ${ }^{3}$ Department of Fisheries Product Technology, Faculty of Fisheries and Marine Science, Universitas Borneo Tarakan. Jl. Amal Lama No. 1, Tarakan \\ 77115, North Kalimantan, Indonesia \\ ${ }^{4}$ Department of Accounting, Politeknik Negeri Tanah Laut. Jl. A. Yani Km. 6, Pemuda, Tanah Laut 70815, South Kalimantan, Indonesia \\ ${ }^{5}$ Borneo Marine Research Institute, Malaysia Sabah University. 88400 Kota Kinabalu, Sabah, Malaysia \\ ${ }^{6}$ Universitas Pertahanan Indonesia. IPSC Area, Sentul, Sukahati, Citeureup, Bogor 16810, West Java, Indonesia \\ ${ }^{7}$ Department of Aquatic Resource Management, Faculty of Fisheries and Marine Science, Universitas Diponegoro. Jl. Prof. H. Soedarto, S.H, Tembalang, \\ Semarang 50275, Central Java, Indonesia
}

Manuscript received: 5 December 2020. Revision accepted: 17 January 2021.

\begin{abstract}
Indarjo A, Salim G, Nugraeni CD, Zein M, Ransangan J, Prakoso LY, Suhirwan, Anggoro S. 2021. Length-weight relationship, sex ratio, mortality and growth condition of natural stock of Macrobrachium rosenbergii from the estuarine systems of North Kalimantan, Indonesia. Biodiversitas 22: 846-857. Giant prawns (Macrobrachium rosenbergii) in North Kalimantan Province, Indonesia are commonly found inhabiting estuarine areas in Salimbatu Village (Bulungan District), Tepian Village (Nunukan District) and Buong Baru and Sesayap Villages (Tana Tidung District). The present study was conducted to analyze the relationship between length and weight, sex ratio, mortality, and growth condition index of the naturally occurring giant prawns in three districts namely Bulungan, Nunukan, and Tana Tidung in the North Kalimantan Province, Indonesia. The samplings were carried out for a period of seven months beginning April to November 2020. The results revealed that the giant prawns in Buong Baru Village, Sesayap Village, and Salimbatu Village were characterized to have negative allometric growth patterns. Interestingly, the male giant prawns in Tepian Village were observed to exhibit positive allometric growth pattern. The ratio sex analysis of the giant prawns in the four villages indicated that female prawns were more than male. In terms of size distribution, Salimbatu Village exhibited $60.1 \%$ of prawns measured at $14.02-17.74 \mathrm{~cm}$ (size range of 10.3-47.5 cm). In Tepian Village, 32.9\% of the prawns were observed to measure between 11.20-12.80 cm (size range of 8.0-24.0 $\mathrm{cm}$ ). In Buong Baru Village, it was observed 18.5\% of the prawns measured 22.0-25.5 cm and 29.0-32.5 cm (size range of $15.0-50.0 \mathrm{~cm}$ ), respectively. Finally, $28.3 \%$ of the prawns in Sesayap Village was observed to measure at $12.19-14.02 \mathrm{~cm}$ from the overall size distribution between $6.7-25.0 \mathrm{~cm}$. Relative condition factor of giant prawns found in the waters of Salimbatu Village, Tepian Village, and Buong Baru Village waters and Sesayap Village waters was characterized by thin body shape. The maximum length of male prawns was higher than female prawns in Salimbatu Village, Desa Tepian and Sesayap Village, except in Buong Baru Village where female was longer than male. The exploitation rate and fishing mortalities of prawns were higher in Buong Baru Village, Tana Tidung District. Giant prawn fishery contributes to the socio-economic development of the people in North Kalimantan. Hence, sustainable fishery management of this species, particularly in Buong Baru Village is urgently needed so that it can continue to provide livelihoods to the fishermen in the area.
\end{abstract}

Keywords: Growth condition of natural giant prawn, length-weigh relationship, Macrobrachium rosenbergii, mortality, sex ratio

\section{INTRODUCTION}

Estuarine ecosystems of Indonesia are rich in biodiversity (Suwartiningsih et al. 2017). Many of these biodiversities are exploited for economic development including giant prawns (Indarjo et al. 2020e). The giant prawns (Macrobrachium rosenbergii) are commercially important species and are highly exploited due to their large size (Khasani 2008) and high nutrition contents (Nandlal and Pickering 2005). Giant prawn is indigenous to south and southeast Asian as well as in the northern Oceania and Western Pacific islands, but research activities and commercial purposes have made its distribution expanded throughout the tropical and subtropical regions of the world (Holthuis 1980; New 2002). It occurs in various types of coastal systems including rivers, swamps, lakes, irrigation as well as estuarine systems throughout Indonesia (New 2005). There are several natural populations of the prawn in Indonesia including Musi (South Sumatra), Kalipucang, Tajung Air (West Java) (Hadie et al. 2004), Makassar (South Sulawesi), Banjarmasin (South Kalimantan), Jambi (central Sumatra), and Barito (Kalimantan) (Hadie et al. 2005).

The price of $M$. rosenbergii varies according to places. Indarjo et al. (2020) reported that moderate size of giant prawn in Tepian Village, Nunukan District, is sold at 
Rp.80,000 (USD 5.6)/kg while big sized prawn is sold at Rp.100,000 (USD 7.07)/kg. In Salimbatu Village, Bulungan District the moderate size prawn is sold at Rp.40,000 (USD 2.8)/kg while large-sized $M$. rosenbergii costs at Rp.65,000 (USD 4.6)/kg. In the Buong Baru Village and Sesayap Village, both in Tana District, the price of $M$. rosenbergii is also determined by size. Moderate size prawn is normally sold at Rp.80,000 (USD $5.6) / \mathrm{kg}$ whereas large-sized prawn is sold at Rp.100,000 (USD 7.07)/kg, respectively. In Kalimantan Province, Indonesia, giant prawn is an important fishery resource because it provides income to coastal community (Samuel and Aida 2008). The market price of the prawn in Kalimantan Province ranges from Rp.140,000 (USD 9.9) to 200,000 (USD 14.13) per kilogram depending on sizes (Sukarli 2017).

According to Indarjo et al. (2020d), giant prawn in Tepian Village has huge potential for capture fishery but over-exploitation of the resource can affect its natural population. Unfortunately, no study has been conducted to assess the population dynamics of the prawn in the area. Sofian dan Sari (2018) suggested that the abundance of giant prawns can be affected by excessive exploitation of the resource. Indarjo et al. (2020e) also explained that high market demand of the giant prawn has increased fishing intensity using different gears. Such activity could alter size distribution, condition factor, and the overall population health of the species.

Hossain et al. (2012) reported that $M$. rosenbergii is one of the fast-growing prawns. Giant prawn was reported to grow up to $250 \mathrm{~mm}$ (female) and $320 \mathrm{~mm}$ (male) and weighed more than 300 grams (Wowor and $\mathrm{Ng} \mathrm{2007}$; Holthuis and Ng 2010). Sofian and Sari (2018) reported male $M$. rosenbergii can attain between $7.6-27 \mathrm{~cm}$ in length and from 3 to 297 grams in weight. Likewise, female prawn was reported to achieve between $8.5-18.2 \mathrm{~cm}$ in length and between 5-53 gram in weight. However, Indarjo et al. (2020) suggested that the length of $M$. rosenbergii may vary. The authors reported that male and female prawns can grow up to $14.55+6.55 \mathrm{~cm}$ and $12.4 \pm 4.6 \mathrm{~cm}$, respectively. $M$. rosenbergii is an euryhaline species and able to survive in estuarine areas (Ali and Waluyo 2015) with different levels of salinities. According to Indarjo et al. (2020), giant prawn can survive in 6-7 ppt salinity levels whereas New (2002) observed that giant prawn survive in 15 to 20 ppt salinity levels.

Due to attractive pricing, the number of fishermen fishing for the prawn in several villages within the three districts on the North Kalimantan Province especially in Balungan, Nunukan, and Tana Tidung has drastically increased. In addition, many fishing gears (e.g. langgian (scoop net), tuguk (filtering device), jala (cast nets), empang lulung (barrier trap), bengkirai bilah (poot traps) and pancing (hook and lines), rawai udang (long lines), rompong and pukat rantau (fish aggregating devices)) have also been invented to effectively catch the prawns. In recent years, stroom (electrical fishing) has also been practiced in some areas.

The high number of fishermen involved in fishing using various fishing gears can have negative impact on the natural stock of the prawn and may lead to overfishing. In fact, there is already sign of stock reduction being experienced by the fishermen in this province, especially in the Tana Tidung District (Hanifah 2019). Unfortunately, the effects of fishing activity on the natural stocks of giant prawns in the three districts of North Kalimantan Province are difficult to evaluate due to no thorough studies were conducted on the status of natural stocks of the prawn in those areas. Such situation makes it difficult for the relevant agencies to implement sustainable management of the giant prawn resource. Hence, the present study was conducted to examine the status of length-weight relationship, sex ratio, mortality, and growth condition of the giant prawns in the three districts (Bulungan, Nunukan, and Tana Tidung) in the North Kalimantan Province, Indonesia.

\section{MATERIALS AND METHODS}

\section{Sampling}

Sampling sites and study period

The study of the giant prawn was conducted in the coastal waters of three districts (Bulungan, Nunukan and Tana Tidung) in the North Kalimantan, Indonesia (Figure 1). Samples of the prawn were collected from four villages namely Salimbatu Village (Tanjung Palas Tengah Subdistrict, Bulungan District), Tepian Village (Sembakung Subdistrict, Nunukan District), Buong Baru Village (Batayau Subdistrict, Tana Tidung District), and Sesayap Village (Sesayap Hilir Subdistrict, Tana Tidung District). The study was conducted for seven months from April 2020 to November 2020.

\section{Sample collection}

The collection of giant prawn (M. rosenbergii) specimens was done in the fields following the fishermen fishing technique unique to the study sites. The sampling of the prawn in Salimbatu was achieved by using prawn trap called $b u b u$ made of high-density polyethylene (HDPE) netting (Figure 2.A). Sample collection in Buong Baru was done by using bubu or prawn trap made of bamboo (Figure 2.B). The sample collection in Tepian was achieved by using casting net, called jala by the local peoples (Figure 2.C). Samples of prawns in Sesayap were collected using casting net (Figure 2.D). Then, the prawns were sorted out after capture and identified following Holthius (1980) and Powell (1983).

\section{Sample measurement}

The total length (TL), carapace length (CL), total body weight (BW) and sexes of all specimens of the giant prawn were recorded and determined, respectively. A total of 404 prawn specimens were collected using prawn trap in Salimbatu; 621 specimens of prawn from Tepian; 81 specimens from Buong Baru and 53 specimens from Sesayap. The total length of all the prawns were assigned into 10 length classes interval (Tables 3-6). 


\section{Sex determination}

The male and female giant prawns were distinguished following Aflalo et al. (2006). Briefly, the four main differences of the male and female prawns were specifically examined in order to assign the sex of the prawn specimens. It was noted that the $2^{\text {nd }}$ pereiopods (chelipeds) of the male prawn is longer than the female prawn. The abdomen of male prawn is slimmer than the abdomen of female prawn. The carapace of the male prawn is larger than the female prawn. The sex of the prawns was determined based on the location of the sex organ (gonophores). The gonophores of the male prawn are located on the $5^{\text {th }}$ pereiopods whereas the gonophores of female prawn are located on the $3^{\text {rd }}$ pereiopods.

\section{Physicochemical parameters}

The physicochemical parameters including temperature, salinity, $\mathrm{pH}$, and dissolved oxygen were recorded in the sampling sites (Salimbatu, Tepian and Sesayap) except for Buong Baru due to Covid-19. The location of each sampling site was recorded using the Global Positioning System (GPS). The temperature, salinity and $\mathrm{pH}$ were directly measured in the field (in situ) whereas the dissolved oxygen was measured ex-situ at the Water Quality Laboratory of the Faculty of Fisheries and Marine Sciences, University of Borneo Tarakan, Indonesia.

\section{Data analysis}

Sex ratio

Sex ratio (male: female) was calculated by dividing the number of male/female specimens with the total number of specimens analyzed. Then, sex ratios were then tabulated according to its sampling site. The sex determination was done following sex identification guidelines suggested by Aflalo et al. (2006).

\section{Length-weight relationship}

Regression analysis was performed on the lengthweight measurement according to the following model (Pauly 1984).
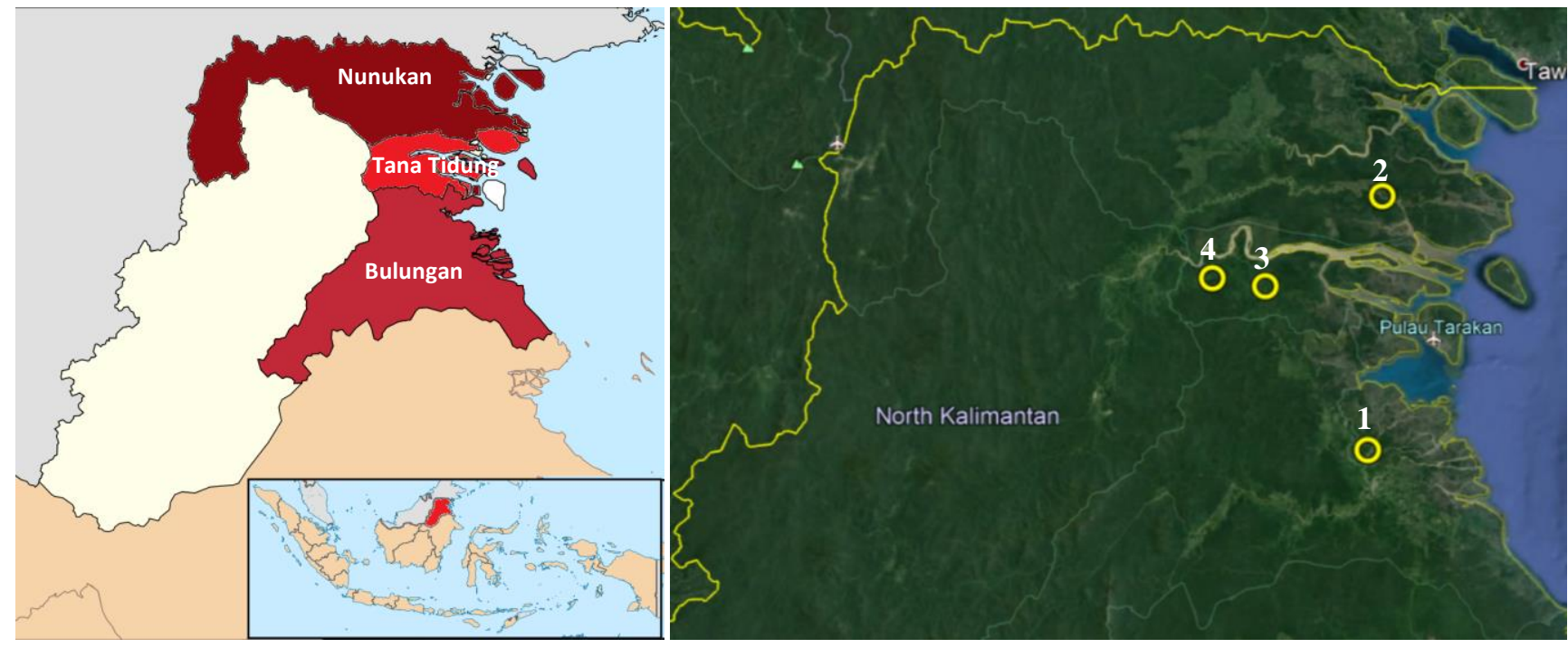

Figure 1. Study sites in the three districts (Bulungan, Nunukan and Tana Tidung) on the North Kalimantan Province, Indonesia. 1. Salimbatu Village, 2. Tepian Village, 3. Buong Baru Village 4. Sesayap Village
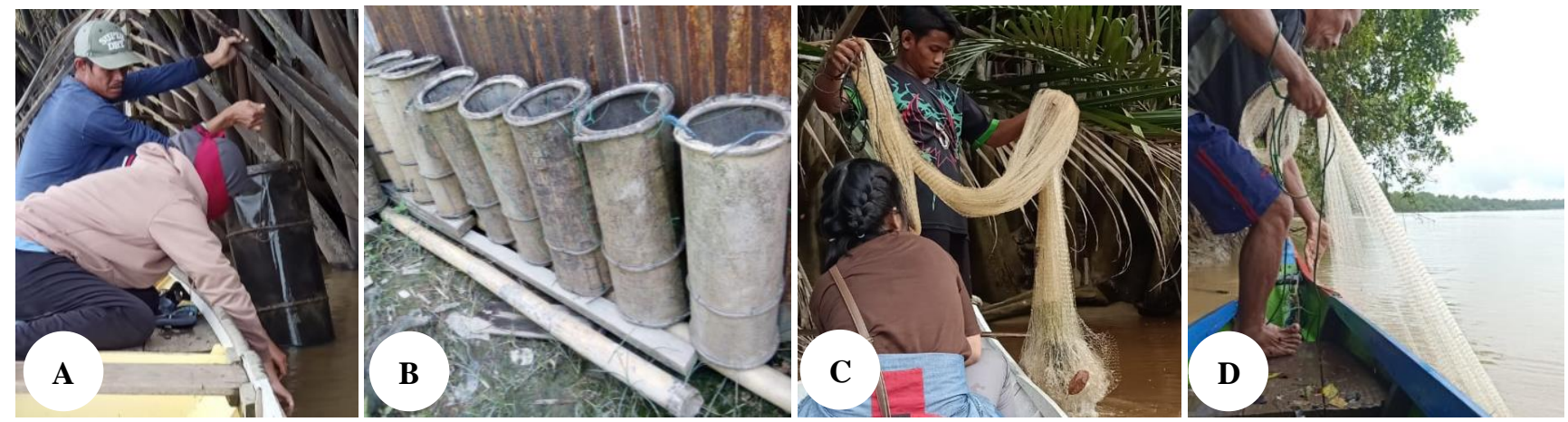

Figure 2. Fishing techniques used by fishermen in different sampling sites. A. Prawn traps, bubu (Salimbatu Village); B. Prawn trap, bubu (Buong Baru Village); C. Casting net (Tepian Village); D. Casting net (Sesayap Village) 
$\mathrm{W}=\mathrm{aL}^{\mathrm{b}}$

Where, $\mathrm{W}$ is body wet weight $(\mathrm{g}), \mathrm{L}$ is total length $(\mathrm{cm})$, a and $\mathrm{b}$ are parameters of the power equation.

The linearized equation of the model was expressed in the following equation (Effendie 2002).

$\log _{10} \mathrm{~W}=\log _{10} \mathrm{a}+\operatorname{blog}_{10}(\mathrm{~L})$

Where, W: total weight (gram); L: otal length (mm); a: ntercept and b: slope (growth exponent).

Condition factor

Relative condition factor ' $\mathrm{Kn}$ ' introduced by Le Cren (1985) was estimated by the following formula:

$$
\mathrm{Kn}=\frac{W}{W}
$$

Where, W: actual weight of fish $(\mathrm{g}) ; \hat{\mathrm{W}}$ : expected weight of fish $(\mathrm{g})$. The $\hat{\mathrm{W}}$ was estimated from the logarithmic transformed of the allometric growth formula:

$$
\log W=\log a+b \log L
$$

Condition index of the fish was categorized into five categories i.e. very thin $(\mathrm{Kn}=0.01-0.50)$, thin $(\mathrm{Kn}=0.51$ $0.99)$, ideal $(\mathrm{kn}=1.0)$, fat $(\mathrm{kn}=1.01-1.50)$, and very fat (kn>1.50) (Firdaus and Salim 2011; Salim 2013; Salim 2015; Firdaus et al. 2018; Firdaus et al. 2020; Indarjo et al. 2020a; Indarjo et al. 2020b; Indarjo et al. 2020c).

\section{Absolute growth}

The absolute growth of the prawns in different sampling sites was estimated using the Von Bertalanfy Growth Function (Sparre and Venema 1999) as follow:

$$
\mathrm{Lt}=\mathrm{L} \infty\left(1-\mathrm{e}^{-\mathrm{k}(\mathrm{t}-\mathrm{t} 0)}\right)
$$

Where, Lt: length of $M$. rosenbergii at age t (unit time); Lo: maximum length (asymptotic length) of $M$. rosenbergii; K: growth coefficient $M$. rosenbergii (per unit time); $\mathrm{t}_{0}$ : hypothetical age of the $M$. rosenbergii at length equals to zero.

\section{Age structure}

Age structure parameters estimated using the mode class shift method associated with the Von Bertalanffy Growth Function (Sparre et al. 1999) as follow:

$$
\begin{aligned}
& (\Delta \mathrm{L} / \Delta \mathrm{t})=\left(\mathrm{L}_{2}-\mathrm{L}_{1}\right) /\left(\mathrm{t}_{2}-\mathrm{t}_{1}\right) \\
& \mathrm{L}_{(\mathrm{t})}=\left(\mathrm{L}_{2} \pm \mathrm{L}_{1}\right)
\end{aligned}
$$

Where, $\Delta \mathrm{L} / \Delta \mathrm{t}$ : Relative growth of $M$. rosenbergii; $\Delta \mathrm{L}$ : Length of $M$. rosenbergii; $\Delta \mathrm{t}$ : Time difference in sampling of $M$. rosenbergii; $\mathrm{L}_{(\mathrm{t})}$ : Mean length at age $\mathrm{t}$.

Then, by plotting $\mathrm{L}_{(\mathrm{t})}$ and $(\Delta \mathrm{L} / \Delta \mathrm{t})$, a linear equation can be derived as follow:

$$
\mathrm{Y}=\mathrm{a} \pm \mathrm{bx}
$$

Where, $\mathrm{a}=\left(\left(\sum \mathrm{y} / \mathrm{n}\right)-\left(\mathrm{b}\left(\sum \mathrm{x} / \mathrm{n}\right)\right)\right) ; \mathrm{b}=\left(\mathrm{n} \sum(\mathrm{xy})-\left(\sum \mathrm{x}\right)(\right.$ $\left.\left.\sum \mathrm{y}\right)\right) /\left(\mathrm{n} \sum \mathrm{x}^{2}-\left(\sum \mathrm{x}\right)^{2}\right)$

The linear regression equation can be used to calculate the asymptotic length $(\mathrm{L} \infty)$, namely-a/b, and the growth coefficient $(\mathrm{K})$, namely-b of $M$. rosenbergii.

The theoretical age of $M$. rosenbergii when the length is equal to zero can be estimated separately using empirical equations (Pauly 1984) as follows:

$\log 10\left(-\mathrm{t}_{0}\right)=-0,3922-0,275(\log 10 \mathrm{~L} \infty-1,038(\log 10 \mathrm{~K})$

Where, L $\infty$ : Asymptotic length of $M$. rosenbergii $(\mathrm{cm})$; $\mathrm{K}$ : Growth coefficient of $M$. rosenbergii; $\mathrm{t}_{0}$ : hypothetical age of $M$. rosenbergii at length equals to zero (year).

\section{Mortality}

Natural mortality (M) of $M$. rosenbergii was estimated using Pauly's empirical formula (1980) as follows: $\log \mathrm{T}$

$\log M=-0.0066-0.279 \log \mathrm{L} \infty+0.6543 \log K+0.4634$

Total mortality $(\mathrm{Z})$ of $M$. rosenbergii was estimated using the Beverton and Holt formula (Sparre and Venema 1998), Sparre et al. (1999) as follows:

$$
\mathrm{Z}=\mathrm{K} \cdot\left[\frac{\mathrm{L}_{\infty}-\bar{L}}{\bar{L}-L^{\prime}}\right]
$$

Fishing mortality (F) of $M$. rosenbergii as follows:

$$
\mathrm{F}=\mathrm{Z}-\mathrm{M}
$$

The exploitation rate (E) of $M$. rosenbergii was estimated following Gulland (1965) as follows:

$$
\mathrm{E}=\mathrm{F} /(\mathrm{F}+\mathrm{M})
$$

Where, E: Exploitation rate of $M$. rosenbergii; Z: Total mortality of $M$. rosenbergii; F: Fishing mortality of $M$. rosenbergii; M: Natural mortality of $M$. rosenbergii.

\section{Statistical analyses}

All the statistical analyses were conducted using the SPSS Windows Statistical Package (Version 26, Chicago, USA). The regression analysis was employed to analyze the length-weight relationship, while Chi-square test was used to analyze the differences in the frequency distributions of fish length and fattiness.

\section{RESULTS AND DISCUSSION}

\section{Sex ratio}

Sex ratio of the giant prawns (M. rosenbergii) in each sampling site analyzed in the current study is presented in Table 1. It was noted that the proportion of male and female prawns is consistent across sampling sites and districts whereby females are generally more than males except in Sesayap whereby the proportion of male and 
female prawns almost equal is $1: 1.03$. The proportion of female prawns in Tepian was found 4.45 times higher than that of males. This is not surprising observation as New Kutty (2010) had reported that the proportion of female $M$. rosenbergii is commonly higher than male. The published proportion of female to male of $M$. rosenbergii in Indonesia ranged from 1.88 times (Sofian and Sari 2018) to 3.67 times (Indarjo et al. 2020e).

Knowledge of sex proportion of naturally occurring $M$. rosenbergii is important because it allows estimation of differential prawn fishing in different periods of the year and the various size groups (Bahuguna 2013). It can also provide information about the abundance of the sex ratio at different times of the year such as during breeding season. In this study, it was observed that the number of female specimens was higher than males. This sex ratio is very similar to that in M. felicinum (Ukagwu and Deekae 2016), M. hetreochirus and M. carcinus (Mejia-Ortize et al. 2001), M. brasiliense (Mantellato and Barbosa 2005), M. dux (Arimoro and Meye 2007), M. macrobrachion and $M$. vollenhovenii (Lawal-Are and Owolabi 2012). This indicates that the natural stocks of the giant prawn (Macrobrachium spp) are generally dominated by females. Hence, the findings of the present study showed that the natural stocks of the giant prawns in the estuarine systems of North Kalimantan Province are still not over-exploited and no sign of fishing preference over one particular sex. However, the observation in Sesayap Village could be a concern for sustainable fishery management but more studies are needed to examine what factors could remove more females in the area before management strategies can be designed and implemented.

\section{Length and weight relationship}

The present study revealed that the total length (TL), carapace length (CL) and body weight (BW) of male prawns in the three sampling sites (Tepian, Salimbatu, and Sesayap) were recorded higher than that of female prawns (Tabel 2). One exception to this observation was in Buong Baru whereby male prawns were observed to have bigger size (TL, CL and BW) compared to female prawns (Table 2 ). In terms of total length distribution, it was observed that all prawns in all sampling sites were distributed into the 10 length classes with no significant differences $(p>0.05)$ in frequency between male and female specimens (Table 3 ).

The prawns in Salimbatu were found to have TL that ranged from $10.3-47.5 \mathrm{~cm}$ and CL ranged $4.5-14 \mathrm{~cm}$ and BW ranged from 3.05 to 193 grams, respectively. Meanwhile, the prawns in Tepian observed to have TL and CL that ranged from $8.0-24 \mathrm{~cm}$ and $2.0-12.5 \mathrm{~cm}$ with BW of 2.37-181.8 grams. The prawns caught in Buong Baru and Sesayap were observed to have TL that ranged from 15.0-50 cm (CL: $5.5-13 \mathrm{~cm}$ ) and 6.7-25 cm (CL: 2.0-13.0 $\mathrm{cm})$ with BW of 9.67-214.47 grams and 3.84-141.09 grams, respectively (Table 2). The present observations on the TL of the giant prawns in the four villages were in agreement with the observations by the previous studies. New Kutty (2010) observed that $M$. rosenbergii can reach TL of 9.9-19.3 cm with BW of 10.86-69.86 grams. Sofian and Sari (2018) also reported $M$. rosenbergii is able to reach TL between 7.6-27 cm with $\mathrm{BW}$ of 3-297 grams. Indarjo et al. (2020d) and (2020e) reported that $M$. rosenbergii can reach TL of 7.8-21.1 cm and 9.9-19.3 cm, respectively. Regardless of sex, the giant prawns caught in Salimbatu recorded CL that ranged between $2-14 \mathrm{~cm}$. This seems to be an advantage to the prawn population in the area as Hadie and Hadie (2012) reported that prawns with shorter CL would have greater meat proportion.

The present study also examined the size (length) distribution of the naturally occurring prawns in the four selected villages on the North Kalimantan Province. Table 3 shows the TL distribution of giant prawns. In Salimbatu, $t$ was observed that the male prawns ( $n=182$ samples), females $(n=222)$ and overall $(n=404)$ were mostly found within the 14.02 and $17.74 \mathrm{~cm}$ length class. In Tepian, it was observed that male prawns $(n=114)$ were mostly within the 17.6-19.2 cm length class while the female prawns $(n=507)$ and overall specimens $(n=621)$ were found mostly within the 11.2-12.8 cm length class. In Buong Baru, it was observed that majority of the male prawns $(n=20)$ were found within the $36-39.5 \mathrm{~cm}$ length class. As for female prawns $(n=61)$, majority of them were within the $22.0-25.5 \mathrm{~cm}$ length class. However, overall specimens $(\mathrm{n}=81)$ were observed to be distributed within the two length classes $(22.0-25.5 \mathrm{~cm}$ and $29.0-32.5 \mathrm{~cm}) . \mathrm{In}$ Sesayap, the male prawns $(n=26)$ were found mostly distributed within the 19.51-21.34 cm length class while female prawns $(n=27)$ and overall specimens $(n=53)$ were mostly distributed within the $12.19-14.02 \mathrm{~cm}$ length class. From this study, it was evident that most of the giant prawns caught in the four villages were dominated by young prawns (Sofian and Sari 2018). This shows that the fishermen in the villages may have limited knowledge of the sustainable exploitation of fishery resources.

The calculated exponents of the length-weight (L-W) relationship of the prawns in all sampling sites are given in Table 4. Overall, the L-W relationship of the prawns, both male and female from different sampling sites showed negative allometric growth pattern $(b<3.0)$. Overall and regardless of sex, the prawn stocks in the four villages (Salimbatu, Tepian, Buong Baru, and Sesayap) showed negative allometric growth pattern. Only male prawns from the Tepian showed allometric positive growth pattern (b>3.0)

The relationship between weight and length for crustaceans is usually described by the expression $\mathrm{W}=\mathrm{aL}^{\mathrm{b}}$. The organism is growing isometrically if $b=3$, and when the $\mathrm{b}$ parameter is not equal to 3 , the growth is said to be allometric (Wootton 1992; Enin 1994). Ricker (1975) stated that allometric growth can either be positive $(b>3)$ or negative $(b<3)$. Wootton (1992) reported if the animal gets relatively thinner, then the $b$ value would be less than 3.0 but if it gets plump, the $b$ value would be greater than 3.0. All the overall values of the growth exponent, $b$ in this study were less than 3 (Gayanilo and Pauly 1997) indicating that the prawns are exhibiting negative allometric growth fashion. 
Table 1. The proportion of male and female prawn according to sampling site

\begin{tabular}{lcccccc}
\hline \multicolumn{1}{c}{ Sampling site } & \multicolumn{2}{c}{ Male } & Female & \multirow{2}{*}{ Total } & $\begin{array}{c}\text { Ratio } \\
\text { M:F }\end{array}$ \\
\cline { 2 - 4 } & N & Proportion & N & Proportion & & \multirow{2}{*}{ Tot } \\
Salimbatu Village (Bulungan District) & 182 & $45.05 \%$ & 222 & $54.95 \%$ & 404 & $1: 1.22$ \\
Tepian Village (Nunukan District) & 114 & $18.36 \%$ & 507 & $81.64 \%$ & 621 & $1: 4.45$ \\
Buong Baru Village (Tana Tidung District) & 20 & $24.69 \%$ & 61 & $75.31 \%$ & 81 & $1: 3.05$ \\
Sesayap Village (Tana Tidung District) & 26 & $49.06 \%$ & 27 & $50.94 \%$ & 53 & $1: 1.03$ \\
\hline
\end{tabular}

Note: N: number of specimens

Table 2. Length and weight distributions of the Macrobrachium rosenbergii specimens collected from North Kalimantan, Indonesia

\begin{tabular}{|c|c|c|c|}
\hline Parameter & Male & Female & Overall \\
\hline \multicolumn{4}{|c|}{ Salimbatu Village (Bulungan District) } \\
\hline \multirow[t]{3}{*}{ Total length $(\mathrm{cm})$} & $10.3-47.5$ & $13.2-44.8$ & $10.3-47.5$ \\
\hline & $(18.94 \pm 6.50)$ & $(19.45 \pm 6.11)$ & $(19.22 \pm 6.29)$ \\
\hline & 16.20 & 16.50 & 16.30 \\
\hline \multirow[t]{3}{*}{ Carapace $(\mathrm{cm})$} & $5.0-14.0$ & $4.5-10.5$ & $4.5-14.0$ \\
\hline & $(7.51 \pm 1.71)$ & $(7.19 \pm 0.99)$ & $(7.34 \pm 1.37)$ \\
\hline & 7.00 & 7.20 & 7.00 \\
\hline \multirow[t]{3}{*}{ Weight (g) } & $3.05-193.0$ & $14.6-106.0$ & $3.05-193.0$ \\
\hline & $(47.78 \pm 34.42)$ & $(41.34 \pm 12.77)$ & $(44.24 \pm 25.1$ \\
\hline & 35.75 & 39.28 & 38.14 \\
\hline
\end{tabular}

Tepian Village (Nunukan District)

$\begin{array}{llll}\text { Total length }(\mathrm{cm}) & 8.5-24.0 & 8.0-21.0 & 8.0-24.0 \\ & (16.49 \pm 3.22) & (13.42 \pm 1.77) & (13.98 \pm 2.42) \\ & 17.00 & 13.00 & 13.1 \\ \text { Carapace }(\mathrm{cm}) & 2.0-12.5 & 2.0-10.5 & 2.0-12.5 \\ & (6.60 \pm 2.42) & (4.65 \pm 2.00) & (5.10 \pm 2.69) \\ & 6.50 & 3.50 & 3.60 \\ \text { Weight }(\mathrm{g}) & 5.95-181.80 & 2.37-75.89 & 2.37-181.80 \\ & (53.27 \pm 37.32) & (26.31 \pm 9.64) & (31.26 \pm 20.94) \\ & 42.43 & 24.46 & 24.90\end{array}$

Buong Baru Village (Tana Tidung District)

Total length $(\mathrm{cm}) \quad 26.5-45.0 \quad 15.0-50.0 \quad 15.0-50.0$ $(36.14 \pm 4.98) \quad(29.76 \pm 7.08) \quad(31.34 \pm 7.15)$ $\begin{array}{lll}36.75 & 30.00 & 30.00\end{array}$

Carapace $(\mathrm{cm}) \quad 7.50-13.0 \quad 5.5-13.0 \quad 5.5-13.0$ $\begin{array}{lll}(11.02 \pm 1.45) & (8.73 \pm 1.71) \quad(9.3 \pm 1.92)\end{array}$ $\begin{array}{lll}11.25 & 8.50 & 9.00\end{array}$

Weight $(\mathrm{g}) \quad 26.65-154.49 \quad 9.67-214.47 \quad 9.67-214.47$ $(106.86 \pm 37.28)(53.57 \pm 37.76)(66.73 \pm 43.98)$ $\begin{array}{lll}112.78 & 42.18 & 52.33\end{array}$

Sesayap Village (Tana Tidung District)

$\begin{array}{llll}\text { Total length }(\mathrm{cm}) & 14.5-25.0 & 6.7-23.2 & 6.7-25.0 \\ & (20.97 \pm 3.11) & (14.48 \pm 3.83) & (17.66 \pm 4.76) \\ & 21.1 & 13.5 & 18.0 \\ \text { Carapace }(\mathrm{cm}) & 6.0-13.0 & 2.0-12.5 & 2.0-13.0 \\ & (10.52 \pm 2.13) & (7.04 \pm 2.42) & (8.75 \pm 2.86) \\ & 11.0 & 7.0 & 8.2 \\ \text { Weight }(\mathrm{g}) & 25.78-141.09 & 3.84-110.23 & 3.84-141.09 \\ & (88.95 \pm 37.91) & (35.31 \pm 29.56) & (61.63 \pm 43.14) \\ & 93.43 & 22.52 & 39.53\end{array}$

Table 3. Length class distribution of the Macrobrachium rosenbergii specimens from North Kalimantan, Indonesia

\begin{tabular}{|c|c|c|c|c|}
\hline Length class & Size range $(\mathrm{cm})$ & Male & Female & Overall \\
\hline \multicolumn{5}{|c|}{ Salimbatu Village (Bulungan District) } \\
\hline 1 & $10.30-14.02$ & 19 & 8 & 27 \\
\hline 2 & $14.02-17.74$ & $103 *$ & $140 *$ & $243 *$ \\
\hline 3 & $17.74-21.46$ & 10 & 13 & 23 \\
\hline 4 & $21.46-25.18$ & 23 & 14 & 37 \\
\hline 5 & $25.18-28.90$ & 11 & 23 & 34 \\
\hline 6 & $28.90-32.62$ & 6 & 14 & 20 \\
\hline 7 & $32.62-36.34$ & 7 & 6 & 13 \\
\hline 8 & $36.34-40.06$ & 0 & 3 & 3 \\
\hline 9 & $40.06-43.78$ & 1 & 0 & 1 \\
\hline \multirow{2}{*}{10} & $43.78-47.50$ & 2 & 1 & 3 \\
\hline & Total $^{* *}$ & $182^{\mathrm{a}}$ & $222^{\mathrm{a}}$ & $404^{\mathrm{a}}$ \\
\hline \multicolumn{5}{|c|}{ Tepian Village (Nunukan District) } \\
\hline 1 & $8.00-9.60$ & 1 & 3 & 4 \\
\hline 2 & $9.60-11.20$ & 3 & 18 & 21 \\
\hline 3 & $11.20-12.80$ & 12 & $192 *$ & $204 *$ \\
\hline 4 & $12.80-14.40$ & 17 & 161 & 178 \\
\hline 5 & $14.40-16.00$ & 17 & 93 & 110 \\
\hline 6 & $16.00-17.60$ & 18 & 26 & 44 \\
\hline 7 & $17.60-19.20$ & $26^{*}$ & 11 & 37 \\
\hline 8 & $19.20-20.80$ & 8 & 2 & 10 \\
\hline 9 & $20.80-22.40$ & 9 & 1 & 10 \\
\hline \multirow[t]{2}{*}{10} & $22.40-24.00$ & 3 & 0 & 3 \\
\hline & Total $^{* *}$ & $114^{\mathrm{a}}$ & $507^{\mathrm{a}}$ & $621^{\mathrm{a}}$ \\
\hline
\end{tabular}

Buong Baru Village (Tana Tidung District)

$\begin{array}{ccccc}1 & 15.0-18.5 & 0 & 2 & 2 \\ 2 & 18.5-22.0 & 0 & 4 & 4 \\ 3 & 22.0-25.5 & 0 & 15^{*} & 15^{*} \\ 4 & 25.5-29.0 & 2 & 8 & 10 \\ 5 & 29.0-32.5 & 2 & 13 & 15^{*} \\ 6 & 32.5-36.0 & 5 & 8 & 13 \\ 7 & 36.0-39.5 & 7^{*} & 6 & 13 \\ 8 & 39.5-43.0 & 2 & 2 & 4 \\ 9 & 43.0-46.5 & 2 & 2 & 4 \\ 10 & 46.5-50.0 & 0 & 1 & 1 \\ & \text { Total }^{* *} & 20^{\mathrm{a}} & 61^{\mathrm{a}} & 81^{\mathrm{a}}\end{array}$

Sesayap Village (Tana Tidung District)

\begin{tabular}{ccccc}
1 & $6.70-8.53$ & 0 & 1 & 1 \\
2 & $8.53-10.36$ & 0 & 1 & 1 \\
3 & $10.36-12.19$ & 0 & 2 & 2 \\
4 & $12.19-14.02$ & 0 & $15^{*}$ & $15^{*}$ \\
5 & $14.02-15.85$ & 3 & 2 & 5 \\
6 & $15.85-17.68$ & 1 & 1 & 2 \\
7 & $17.68-19.51$ & 2 & 2 & 4 \\
8 & $19.51-21.34$ & $8^{*}$ & 0 & 8 \\
9 & $21.34-23.17$ & 6 & 2 & 8 \\
10 & $23.17-25.00$ & 6 & 1 & 7 \\
& Total $^{* *}$ & $26^{\mathrm{a}}$ & $27^{\mathrm{a}}$ & $53^{\mathrm{a}}$ \\
\hline
\end{tabular}

Notes: "the length class in which the median value is recorded; ${ }^{* *}$ different letters indicate significant differences in terms of frequency distributions. 
Table 4 shows the L-W relationships of the giant prawns in the four villages in North Kalimantan Province. It was observed that the prawns in three villages exhibited negative $\mathrm{Y}$-intercept of the linear regression between weight and length. Whether or not these values have significant biological consequences to the prawns in the areas is something very interesting but with the limited amount of data gathered in the present study, interpretation of this observation cannot be accurately done. It was reported that the $\mathrm{L}-\mathrm{W}$ relationships of $M$. rosenbergii are affected by the age of the animal (Ming et al. 2016). Growth pattern for $M$. rosenbergii varies according to life stages (Primavera et al. 1998; Kurup et al. 2000; Lalrinsanga et al. 2012).

Such growth pattern is always referred to as the "leapfrog" growth pattern (Karplus et al. 1991). The values of the allometry coefficient (b) of the prawns in the present values were in agreement with previous studies in terms of all showed negative allometric growth (Table 5) except for the prawn stock in Salimbatu. The allometry coefficient of the $M$. rosenbergii in the North Kalimantan tends to have similar growth characteristics with the prawn stocks in Sarawak, Malaysia (Khairul Adha et al. 2016). This may be explained by the close relatedness of the prawns since Sarawak and North Kalimantan are adjacent.

In the present study, the allometry coefficient of the prawn in Sesayap BW-TL was less than $3(b=2,7)$ which may indicate that the increase in weight of the prawns in the area is relatively slower than the length (Effendie 2002). Such observation was in accordance with the finding of Sofian and Sari (2018) who found lower allometry coefficient value $(b<3.0)$ of the giant prawns in the Ogan River, Ogan Ilir District. However, the male prawns caught in Tepian exhibited higher allometry coefficient $(b=3.1)$ which indicates that weight gain is faster than the length. This is not a surprising finding as Murni (2004) also reported high allometry coefficient (b>3.0) of giant prawns in Kapuas Pontianak, West Kalimantan. The differences in allometry coefficient were reported to influence by food abundance and availability, water conditions and analytical methods (Raswin et al. 1981). Furthermore, the growth of any organism depends on the intrinsic factors (genetic makeup) as well as the extrinsic (environmental) factors acting on the individual throughout its ontogenetic development. According to Hartnoll (1982), the exogenous factors that mostly influence the growth of crustaceans are temperature and food availability.

\section{Condition index}

Analysis of the condition index of the giant prawn specimens revealed little variations in terms of body shape among the prawns collected from different sampling sites (Table 6). Different values of the condition index imply different body shapes of the prawns (Lagler 1961). The prawn specimens collected from Salimbatu exhibited 4 different body shapes which are very thin, thin, fat and very fat. The male prawn specimens in this sampling site seemed to have a wide distribution of body shape compared to the female prawns. More than half $(51.8 \%)$ of the female prawns in Salimbatu consisted of thin specimens. In contrast, the male prawns in this area showed to have fat body shape (37.4\%), but small letters overall explained that $44.8 \%$ of body shape is thin. The prawns in Tepian were noted to have similar body shapes to the one in Salimbatu, however more than half male prawns $(57.9 \%)$; females $(57.8 \%$ and overall $(57.8 \%)$ have a thin body shape. This is the same as the shrimp found in Sesayap where more than half male prawns (69.2\%); female $(51.9 \%)$ and overall $(60.4 \%)$ have a thin body shape. And that the prawns in Buong Baru in the Tana Tidung District were mostly exhibited thin body shape for male $(65 \%)$; female $(44.3 \%)$ and overall $(49.4 \%)$.

Table 4. Estimated parameters of length-weight relationships $(\mathrm{W}=\mathrm{aLb})$ of male, female and overall Macrobrachium rosenbergii specimens collected from North Kalimantan Province, Indonesia

\begin{tabular}{|c|c|c|c|}
\hline Sampling site & Male & Female & Overall \\
\hline $\begin{array}{l}\text { Salimbatu Village } \\
\text { (Bulungan District) }\end{array}$ & $\begin{array}{c}\mathrm{W}=0.0822 \mathrm{~L}^{1.2075} \\
\mathrm{~b}=1.2 \\
\text { Allometric negative }\end{array}$ & $\begin{array}{c}\mathrm{W}=1.1714 \mathrm{~L}^{0.335} \\
\mathrm{~b}=0.3\end{array}$ & $\begin{array}{c}\mathrm{W}=0.6488 \mathrm{~L}^{0.7509} \\
\mathrm{~b}=0.7 \\
\text { Allometric negative }\end{array}$ \\
\hline $\begin{array}{l}\text { Tepian Village } \\
\text { (Nunukan District) }\end{array}$ & $\begin{array}{c}\mathrm{W}=-2.2417 \mathrm{~L}^{3.196} \\
\mathrm{~b}=3.1\end{array}$ & $\begin{array}{l}\mathrm{W}=-1.0623 \mathrm{~L}^{2.1864} \\
\mathrm{~b}=2.1\end{array}$ & $\begin{array}{l}\mathrm{W}=-1.5028 \mathrm{~L}^{2.5797} \\
\mathrm{~b}=2.5\end{array}$ \\
\hline $\begin{array}{l}\text { Buong Baru Village } \\
\text { (Tana Tidung District) }\end{array}$ & $\begin{array}{c}\mathrm{W}=-1.6425 \mathrm{~L}^{2.3374} \\
\mathrm{~b}=2.3 \\
\text { Allometric negative }\end{array}$ & $\begin{array}{c}\mathrm{W}=-1.5413 \mathrm{~L}^{2.1738} \\
\mathrm{~b}=2.1\end{array}$ & $\begin{array}{l}\mathrm{W}=-1.8953 \mathrm{~L}^{2.4377} \\
\mathrm{~b}=2.4 \\
\text { Allometric negative }\end{array}$ \\
\hline $\begin{array}{l}\text { Sesayap Village } \\
\text { (Tana Tidung District) }\end{array}$ & $\begin{array}{l}\mathrm{W}=-1.6248 \mathrm{~L}^{2.6778} \\
\mathrm{~b}=2.7 \\
\text { Allometric negative }\end{array}$ & $\begin{array}{c}\mathrm{W}=-1.6976 \mathrm{~L}^{2.7301} \\
\mathrm{~b}=2.7 \\
\text { Allometric negative }\end{array}$ & $\begin{array}{l}\mathrm{W}=-1.6997 \mathrm{~L}^{2.7334} \\
\mathrm{~b}=2.7 \\
\text { Allometric negative }\end{array}$ \\
\hline
\end{tabular}

Note: BW: body weight; TL: total length; b: growth exponent 
Table 5. Comparison of length-weight relationship of the Macrobrachium rosenbergii in North Kalimantan Province, Indonesia with other studies

\begin{tabular}{|c|c|c|c|c|}
\hline Study & Location & $\begin{array}{c}\text { L-W relationship } \\
\left(\mathbf{W}=\mathbf{a L}^{\mathbf{b}}\right)\end{array}$ & $\begin{array}{l}\text { Coefficient of } \\
\text { determinants }\end{array}$ & $\begin{array}{c}\text { Number of } \\
\text { samples }\end{array}$ \\
\hline Present study & $\begin{array}{l}\text { Salimbatu Village (Bulungan District, } \\
\text { North Kalimantan Province, Indonesia) }\end{array}$ & $\mathrm{W}=0.6488 \mathrm{~L}^{0.7509}$ & 0.2254 & 404 \\
\hline Present study & $\begin{array}{l}\text { Tepian Village (Nunukan District, North } \\
\text { Kalimantan Province, Indonesia) }\end{array}$ & $\mathrm{W}=-1.5028 \mathrm{~L}^{2.5795}$ & 0.7699 & 621 \\
\hline Present study & $\begin{array}{l}\text { Buong Baru Village (Tana Tidung District, } \\
\text { North Kalimantan Province, Indonesia) }\end{array}$ & $\mathrm{W}=-1.8953 \mathrm{~L}^{2.4377}$ & 0.6593 & 81 \\
\hline Present study & $\begin{array}{l}\text { Sesayap Village (Tana Tidung District, } \\
\text { North Kalimantan Province, Indonesia) }\end{array}$ & $\mathrm{W}=-1.6997 \mathrm{~L}^{2.7334}$ & 0.9257 & 53 \\
\hline Ming et al. (2016) & Shanghai, China & $\mathrm{W}=5 \times 10^{-6}(\mathrm{TL})^{3.1205}$ & 0.9935 & 456 \\
\hline \multirow[t]{3}{*}{ Khairul Adha et al. (2016) } & Kayan River, Sarawak & $\mathrm{W}=6.350 \mathrm{~L}^{1.172}$ & 0.607 & 20 \\
\hline & Kerang River, Sarawak & $\mathrm{W}=7.320 \mathrm{~L}^{0.792}$ & 0.626 & 30 \\
\hline & Samarahan River, Sarawak & $\mathrm{W}=6.256 \mathrm{~L}^{1.151}$ & 0.573 & 16 \\
\hline Rao (1967) & Hooghly Estuary, India & $\mathrm{W}=7.222 \times 10^{-5} \mathrm{~L}^{3.19346}$ & 0.99013 & 873 \\
\hline Wang (1985) & Hawaii, USA & $\mathrm{W}=3.2 \times 10^{-4}(\mathrm{OL})^{3.2615}$ & 0.978 & 503 \\
\hline Hossain et al. (1987) & Telula River, Bangladesh & $\mathrm{W}=0.00303 \mathrm{~L}^{3.4011}$ & 0.96 & 500 \\
\hline Sampaio and Valenti (1996) & Sao Paulo, Brazil & $\mathrm{W}=1.21 \times 10^{-6} \mathrm{~L}^{3.43}$ & - & - \\
\hline Kunda et al. (2008) & Mymensingh, Bangladesh & $\mathrm{W}=0.008875 \mathrm{~L}^{3.075}$ & 0.99 & 100 \\
\hline Lalrinsanga et al. (2012) & Orissa, India & $\mathrm{W}=0.087694 \mathrm{~L}^{3.3893}$ & 0.9478 & 733 \\
\hline
\end{tabular}

Table 6. Distribution of fish condition factor $\left(\mathrm{K}_{\mathrm{n}}\right)$ or body shape

\begin{tabular}{clccc}
\hline $\begin{array}{c}\text { Sampling } \\
\text { site }\end{array}$ & $\begin{array}{c}\text { Condition factor } \\
\text { (body shape) }\end{array}$ & Male & Female & Overall \\
\hline Salimbatu & Very Thin $\left(\mathrm{K}_{\mathrm{n}}<0.5\right)$ & $11.5 \%$ & $0.9 \%$ & $5.7 \%$ \\
& Thin $\left(0.5 \leq \mathrm{K}_{\mathrm{n}}<1\right.$ & $36.3 \%$ & $51.8 \% *$ & $44.8 \% *$ \\
& Ideal $\left(\mathrm{K}_{\mathrm{n}}=1\right)$ & - & - & - \\
& Fat $\left(1<\mathrm{K}_{\mathrm{n}} \leq 1.5\right)$ & $37.4 \% *$ & $38.3 \%$ & $37.9 \%$ \\
& Very Fat $\left(\mathrm{K}_{\mathrm{n}}>1.5\right)$ & $14.8 \%$ & $9.0 \%$ & $11.6 \%$ \\
Tepian & Very Thin $\left(\mathrm{K}_{\mathrm{n}}<0.5\right)$ & - & - & - \\
& Thin $\left(0.5 \leq \mathrm{K}_{\mathrm{n}}<1\right)$ & $57.9 \% *$ & $57.8 \% *$ & $57.8 \% *$ \\
& Ideal $\left(\mathrm{K}_{\mathrm{n}}=1\right)$ & - & - & - \\
& Fat $\left(1<\mathrm{K}_{\mathrm{n}} \leq 1.5\right)$ & $37.7 \%$ & $40.6 \%$ & $40.1 \%$ \\
& Very Fat $\left(\mathrm{K}_{\mathrm{n}}>1.5\right)$ & $4.4 \%$ & $1.6 \%$ & $2.1 \%$ \\
Buong Baru & Very Thin $\left(\mathrm{K}_{\mathrm{n}}<0.5\right)$ & $5.0 \%$ & $3.3 \%$ & $3.7 \%$ \\
& Thin $\left(0.5 \leq \mathrm{K}_{\mathrm{n}}<1\right)$ & $65.0 \% *$ & $44.3 \% *$ & $49.4 \% *$ \\
& Ideal $\left(\mathrm{K}_{\mathrm{n}}=1\right)$ & - & - & - \\
& Fat $\left(1<\mathrm{K}_{\mathrm{n}} \leq 1.5\right)$ & $30.0 \%$ & $32.8 \%$ & $32.1 \%$ \\
& Very Fat $\left(\mathrm{K}_{\mathrm{n}}>1.5\right)$ & - & $19.7 \%$ & $14.8 \%$ \\
& & & & \\
Sesayap & Very Thin $\left(\mathrm{K}_{\mathrm{n}}<0.5\right)$ & - & - & - \\
& Thin $\left(0.5 \leq \mathrm{K}_{\mathrm{n}}<1\right)$ & $69.2 \% *$ & $51.9 \% *$ & $60.4 \% *$ \\
& Ideal $\left(\mathrm{K}_{\mathrm{n}}=1\right)$ & - & - & - \\
& Fat $\left(1<\mathrm{K}_{\mathrm{n}} \leq 1.5\right)$ & $23.1 \%$ & $48.1 \%$ & $35.8 \%$ \\
& Very Fat $\left(\mathrm{K}_{\mathrm{n}}>1.5\right)$ & $7.7 \%$ & - & $3.8 \%$ \\
\hline
\end{tabular}

Note: *the length class in which the median value is recorded; ** different letters indicate significant differences in term of frequency distributions

The condition factor, $\mathrm{K}$, is widely used in fisheries and fish biology studies as a measure of the degree of robustness of fish. $\mathrm{K}$ is used as an index to reflect fish's physical and biological conditions, and $\mathrm{K}=1$ is the baseline between slender and robust conditions of the organism. If $\mathrm{K}>1$, it means that the animal is stout indicating better condition of robustness of the organism. In the current study, the mean $\mathrm{K}$ value ranged from 0.50 to 1.5 in the wild stocks of M. rosenbergii in the North Kalimantan Province, Indonesia. Similar results of $\mathrm{K}$ were observed in $M$. rosenbergii cultured in rice fields which varied from 0.97 1.17 (Kunda et al. 2008). The fluctuation in the K value in the entire period, for $M$. rosenbergii was similar to the study reported by Lalrinsanga et al. (2012) where the K value ranged from 0.79 in nursery animals to 1.0 to 1.14 in adult broodstock. Judging from the $\mathrm{K}$ values of the prawns in different sampling sites in the present study, majority of the prawn specimens in Sesayap, Salimbatu and Tepian are having total lengths (TL) of $<22 \mathrm{~cm}$ which is considered young. Only prawns in Buong Baru were observed to have bigger size $(\mathrm{TL}>36 \mathrm{~cm}$ ) (Table 3 ). The condition indexes recorded in this study indicate that the prawns in the sampling sites are normal and healthy condition.

\section{Von Bertalanffy Growth Function}

The Von Bertalanffy Growth Function (VBGF) analysis estimated the asymptotic (maximum) total length (TL) of the male prawns in Salimbatu to be at $74.757 \mathrm{~cm}$ which can be attained within 557 days of age and growth coefficient of $0.0206 \mathrm{~cm} /$ day with the $t_{0}$ value of -1.6271 . For female prawns, the maximum TL was estimated at $57.172 \mathrm{~cm}$ which attainable within 419 days of age at growth coefficient of $0.0297 \mathrm{~cm} /$ day and with the $t_{0}$ value of1.4942. The maximum TL of male prawns in Tepian was estimated at $28.215 \mathrm{~cm}$ which can be attained at 336 days of age with growth coefficient of $0.0354 \mathrm{~cm} /$ day and with 
the $t_{0}$ value of-1.4995. The female prawns were estimated to have maximum TL of $25.623 \mathrm{~cm}$ at the age of 410 days with growth coefficient of $0.026 \mathrm{~cm} /$ day and with a $\mathrm{t}_{0}$ value of-1.6501. The male prawns in Buong Baru was estimated to have maximum TL of $46.649 \mathrm{~cm}$ at 210 days of age at the growth coefficient of $0.0519 \mathrm{~cm} /$ day and with the $t_{0}$ value of-1.2668 while female prawns were estimated to attain maximum TL of $52.113 \mathrm{~cm}$ at the age of 319 days achievable at the growth coefficient of $0.0344 \mathrm{~cm} /$ day and the $t_{0}$ value of-1.439. The estimated maximum TL of male prawns in Sesayap was at $25.969 \mathrm{~cm}$ that is achievable within 216 days of age at growth coefficient of 0.0514 $\mathrm{cm} /$ day and with $\mathrm{t}_{0}$ value of-1.3412. As for female prawns, the maximum TL was estimated at $24.514 \mathrm{~cm}$ at the age of 375 days with a growth coefficient of $0.0331 \mathrm{~cm} /$ day and $\mathrm{t}_{0}$ value of-1.5465.

Based on this estimation, it is suggested that the maximum TL of male shrimp in Salimbatu, Tepian and Sesayap was larger than that of female populations in the respective fishing grounds. This is in accordance with the finding of Sofian and Sari (2018) who reported that the maximum TL $(28.74 \mathrm{~cm})$ of male prawns was larger than that of female prawns $(19.08 \mathrm{~cm})$. Murni (2004) also reported the maximum TL $(29.3 \mathrm{~cm})$ of male prawns in Kapuas River Estuary in Pontianak, West Kalimantan was larger than that in female prawns $(25 \mathrm{~cm})$. The current study observed that the female prawns in Buong Baru exhibited larger maximum TL than that in male prawns. According to Sofian and Sari (2018), growth differences among different sexes of $M$. rosenbergii could be influenced by the habitat characteristics particularly water quality. However, due to lack of information, the effect of water quality on the estimated maximum growth (TL) of $M$. rosenbergii in the present study, cannot be determined.

\section{Estimated mortality and exploitation rate}

The estimated mortalities of the prawns in each of the four villages is given in Table 7 . It was observed that the male $(118.7 \%)$ and female $(117.9 \%)$ prawns in Sesayap recorded the highest total mortality $(\mathrm{Z})$. The highest fishing mortality $(\mathrm{F})$ of male $(64.1 \%)$ and female $(49 \%)$ prawns were recorded in Buong Baru. The male prawns $(80.5 \%)$ in Salimbatu and female prawns $(99.6 \%)$ in Tepian recorded the highest natural mortality $(\mathrm{M})$. As for exploitation rate (E), the male $(54.5 \%)$ and female $(41.9 \%)$ prawns in Buong Baru were observed to be highly exploited. According to Indarjo (2020a), exploitation rate exceeds $50 \%$ can indicate that the fishery resource is experiencing overfishing. Yudiati et al. (2020) suggested one of the reasons for overexploitation is high market demand and attractive pricing. This is particularly true in Buong Baru where prawns are sold at Rp 80,000.00 (USD 5.6) to Rp 100,000.00 (USD $7.07) / \mathrm{kg}$.

\section{Physicochemical parameters}

The results of the measurement of the physicochemical parameter are given in Table 8 . It was noted that the physicochemical properties of the water in the three sampling sites (fishing grounds) were not much different and within the suitable range for $M$. rosenbergii (Hadie and Supriyatna 1985; Murtidjo 1992; Ali 2009; Waluyo et al. 2018).

Generally, the giant prawn populations in the four fishing grounds (Salimbatu, Tepian, Sesayap and Buong Baru) are dominated by female prawns. In terms of size distribution, most prawns caught in the fishing grounds are considered young having total length that ranged from 11$25 \mathrm{~cm}$. The length-weight relationship of the prawns in all fishing grounds was characterized by negative allometric growth pattern which indicates that the weight gain is slower than the length increment. As for condition index (body shape), majority of the prawns in the fishing grounds were thin. Based on the VBGF analysis, the prawns in the fishing grounds have shown to have different asymptotic (estimated maximum) lengths and expected to be achieved in different time periods. Interestingly, the prawns in the four fishing grounds exhibited different levels of mortality and exploitation rates. The giant prawns in two fishing grounds namely Tepian and Sesayap were observed to experience high natural and total mortality, respectively. However, situation in Buong Baru was particularly interesting because the prawns in the area were shown to experience high fishing mortality and high exploitation rate, a worrisome situation that requires more attention and immediate conservation efforts to prevent further exploitation of the prawns in area.

Table 7. Estimated parameters of mortality of male and female Macrobrachium rosenbergii specimens collected from North Kalimantan Province, Indonesia

\begin{tabular}{llcc}
\hline \multicolumn{1}{c}{ Sampling site } & $\begin{array}{c}\text { Parameters of } \\
\text { mortality }\end{array}$ & Male & Female \\
& Total & $109.1 \%$ & $110.6 \%$ \\
\hline Salimbatu Village & Natch & $28.6 \%$ & $42.3 \%$ \\
(Bulungan District) & Exploitation rate & $80.5 \% *$ & $68.3 \%$ \\
& & $26.2 \%$ & $38.2 \%$ \\
& Total & $117.1 \%$ & $110.6 \%$ \\
Tepian Village & Catch & $37.9 \%$ & $11.0 \%$ \\
(Nunukan District) & Natural & $79.2 \%$ & $99.6 \% *$ \\
& Exploitation rate & $32.4 \%$ & $9.9 \%$ \\
& & & \\
& Total & $117.7 \%$ & $117 \%$ \\
Buong Baru Village & Catch & $64.1 \% *$ & $49 \% *$ \\
(Tana Tidung District) & Natural & $53.6 \%$ & $68 \%$ \\
& Exploitation rate & $54.5 \% *$ & $41.9 \% *$ \\
& & \multicolumn{2}{c}{} \\
& Total & $118.7 \% *$ & $117.9 \% *$ \\
Sesayap Village & Catch & $55.2 \%$ & $31.8 \%$ \\
(Tana Tidung District) & Natural & $63.5 \%$ & $86.1 \%$ \\
& Exploitation rate & $46.5 \%$ & $27 \%$ \\
\hline
\end{tabular}

Note: * the length class in which the median value is recorded 
Table 8. Estimated average parameters of habits of Macrobrachium rosenbergii specimens collected from North Kalimantan, Indonesia

\begin{tabular}{|c|c|c|c|}
\hline Sampling site & \multicolumn{2}{|c|}{$\begin{array}{l}\text { Water quality parameters recorded during } \\
\text { sampling }\end{array}$} & $\begin{array}{l}\text { Water quality parameters reported suitable for } \\
\text { M. rosenbergii }\end{array}$ \\
\hline \multirow[t]{4}{*}{$\begin{array}{l}\text { Salimbatu Village } \\
\text { (Bulungan District) }\end{array}$} & $\mathrm{pH}$ & $5.70-6.30(5.90)$ & $\begin{array}{l}\text { 6.5-8.5 (Hadie and Supriyatna 1985); } \\
\text { 5.84-7.28 (Waluyo et al. 2018) }\end{array}$ \\
\hline & Disolved oxygen (mg/L) & $3.74-7.50(6.19)$ & 5-7 (Murtidjo 1992); 3,22-6,93 (Waluyo et al. 2018) \\
\hline & Salinity (ppt) & & $0-15$ (Waluyo et al. 2018) \\
\hline & Temperature $\left({ }^{\circ} \mathrm{C}\right)$ & $27.0-28.0(27.6)$ & $28-30^{\circ} \mathrm{C}$ (Ali 2009); 24,4-27,2 (Waluyo et al. 2018) \\
\hline \multirow[t]{4}{*}{$\begin{array}{l}\text { Tepian Village } \\
\text { (Nunukan District) }\end{array}$} & $\mathrm{pH}$ & $5.60-6.20(5.90)$ & $\begin{array}{l}\text { 6.5-8.5 (Hadie and Supriyatna 1985); } \\
\text { 5.84-7.28 (Waluyo et al. 2018) }\end{array}$ \\
\hline & Dissolved oxygen $(\mathrm{mg} / \mathrm{L})$ & $2.23-6.36(3.9)$ & 5-7 (Murtidjo 1992); 3.22-6.93 (Waluyo et al. 2018) \\
\hline & Salinity (ppt) & 1 & 0-15 (Waluyo et a. 2018) \\
\hline & Temperature $\left({ }^{\circ} \mathrm{C}\right)$ & $23.8-24.1(24.0)$ & $28-30^{\circ} \mathrm{C}$ (Ali 2009); 24.4-27.2 (Waluyo et al. 2018) \\
\hline \multirow{4}{*}{$\begin{array}{l}\text { Buong Baru Village* } \\
\text { (Tana Tidung District) }\end{array}$} & $\mathrm{pH}$ & - & - \\
\hline & Dissolved oxygen (mg/L) & - & - \\
\hline & Salinity (ppt) & - & - \\
\hline & Temperature $\left({ }^{\circ} \mathrm{C}\right)$ & - & - \\
\hline \multirow[t]{4}{*}{$\begin{array}{l}\text { Sesayap Village } \\
\text { (Tana Tidung District) }\end{array}$} & $\mathrm{pH}$ & $6.2-6.9(6.3)$ & $\begin{array}{l}\text { 6.5-8.5 (Hadie and Supriyatna 1985); } \\
\text { 5.84-7.28 (Waluyo et al. 2018) }\end{array}$ \\
\hline & Dissolved oxygen $(\mathrm{mg} / \mathrm{L})$ & $4.77-7.66(6.1)$ & 5-7 (Murtidjo 1992); 3.22-6.93 (Waluyo et al. 2018) \\
\hline & Salinity (ppt) & 1 & $0-15$ (Waluyo et al. 2018) \\
\hline & Temperature $\left({ }^{\circ} \mathrm{C}\right)$ & 24.0-24.4 (24.2) & $28-30^{\circ} \mathrm{C}$ (Ali 2009); 24.4-27.2 (Waluyo et al. 2018) \\
\hline
\end{tabular}

Note: *Covid-19 incidents; No travel is allowed in April 2020

\section{ACKNOWLEDGEMENTS}

The authors would like to thank the Ministry of Research and Technology/National Innovation Research Agency, Industrial Technology Development and Research, Service Institute (LPPM) of The University of Borneo Tarakan (UBT) for jointly financed this study under The National Innovation System Research Incentives (INSINAS) phase 2 of year 2020. The authors also thank Muhammad Fattah Al-Hafidz, Isnur Julianti, and Anita Who Helped in the field sampling.

\section{REFERENCES}

Aflalo ED, Hoang TTT, Nguyen VH, Lam Q, Nguyen DM, Trinh QS, Raviv S, Sagi A. 2006. A Novel two step procedure for mass production of all male population of giant freshwater prawn Macrobrachium rosenbergii. Aquaculture 256: 468-478. DOI: 10.1016/j.aquaculture.2006.01.035

Ali F. 2009. Mendongkrak Produktivitas Udang Galah Hingga 250 Persen. Penebar Swadaya. Jakarta. [Indonesian]

Ali F, Waluyo A 2015. Tingkat kelangsungan hidup dan pertumbuhan udang galah (Macrobrachium rosenbergii De Man) pada media bersalinitas. Limnotek 22 (1): 42-51. DOI: 10.14203/limnotek.v22i1.30. [Indonesian]

Arimoro FO, Meye JA. 2007. Some aspects of the biology of Macrobrachium dux (Lenz, 1910). (Crustacea: Decapoda: Natania) in River Orogodo Niger Delta, Nigeria. Acta Biol Colomb 12 (1): 111 122.

Bahuguna P. 2013. Sex population structure of Macrobrachium assamense peninsularie (Tiwari) (Crustacea, Decapoda Palaemonidae) in Khoh River, Uttarakhand, India. Intl J Curr Microbiol Appl Sci 2 (10): 382-390.

Effendie MI. 2002. Biologi Perikanan. Yayasan Pustaka Nusatama, Yogyakarta. [Indonesian]

Enin U. 1994. Length-weight parameters and condition factor of two West African prawns. Revista de Biología Tropical 27:121-127.
Firdaus M, Salim G, Cahyadi J, Weliyadi E, Bintoro G. 2020. Model and nature of growth of red snapper fish (Lutjanus argentimaculatus (Forsskål, 1775) fishing catch of bottom fish pots in Bunyu waters, North Kalimantan. AACL Bioflux 13 (3): 1410-1421.

Firdaus M, Lelono TD, Saleh R, Bintoro G, Salim G. 2018. The expression of the body shape in fish species Harpadon nehereus (Hamilton, 1822) in the waters of Juata Laut, Tarakan City, North Kalimantan. AACL Bioflux 11 (3): 613-624.

Firdaus M, Salim G. 2011. Mengkaji populasi ikan puput (Ilisha elongata) yang berasal dari perairan Kota Tarakan. Harpodon 4 (1): 46-53. DOI: 10.35334/harpodon.v4i1.62. [Indonesian]

Gulland JA. 1965. Survival of the youngest stages of fish and its relation to year-class strength. Spec. Pubis int. Commn N.W. Atlant. Fish. 6, 365-371.

Gayanilo FC Jr, Pauly D (eds.). 1997. FAO-ICLARM stock assessment tools.(FiSAT). Reference Manual. FAO Computerized Information Series (Fisheries). No. 8. FAO, Rome

Hadie W, Supriyatna J. 1985. Pengembangan Budidaya Udang Galah dalam Hatchery dan Budidaya. Kanisius, Yogyakarta. [Indonesian]

Hadie LE, Hadie W, Kusmini II, Supriyadi H, Jaelani, Gunadi B. 2004. Rekayasa teknologi udang GIMacro dan rekayasa penyempurnaan hasil rekayasa. Paper presented at Temu Nasional udang galah GIMacro di Yogyakarta, 22-23 Juni 2004. [Indonesian]

Hadie W, Subandriyo, Hadie LE, Noor RR. 2005. Analisis kemampuan daya gabung gen pada genotipe udang galah untuk mendukung program seleksi dan hibridisasi. Jurnal Penelitian Perikanan Indonesia. 11: 51-56. [Indonesian]

Hadie LE, Hadie W. 2012. Perbaikan mutu genetik udang galah (Macrobrachium rosenbergii) berdasarkan seleksi Famili. Berita Biologi 11 (2): 211-219. [Indonesian]

Hanifah. 2019. Tangkapan Udang Galah Mulai Berkurang. https://korankaltara.com/tangkapan-udang-galah-mulai-berkurang. [Indonesian]

Hartnoll RG. 1982. Growth. In: Bliss DE, Abele LG (eds.). The Biology of Crustacea, 2, Embryology, Morphology and Genetics. Academic Press, New York.

Holthuis LB. 1980. FAO species catalogue, 1, shrimps and prawns of the world: 1-271. FAO Fisheries Synopsis 125 (1). FAO, Rome.

Holthuis LB, Ng PKL. 2010. Nomenclature and taxonomy In: New MB, Valenti WC, Tidwell JH, D'Abramo LR, Kutty MN (eds.), Freshwater prawns: Biology and Farming. Wiley Blackwell. Oxford, England. 
Hossain MA, Ali MA, Islam MS, Sahabuddin M, Dewan S. 1987. Lengthweight relationship and condition factor of Macrobrachium rosenbergii (De Man) of Tetulia River. Bangladesh J Fish 10 (1): 8995.

Hossain MY, Ohtomi J, Jaman A, Jasmine S, et al. 2012. Life history traits of the Monsoon River prawn Macrobrachium malcolmsonii (Milne-Edwards, 1844) (Palaemonidae) in the Ganges (Padma) River, northwestern Bangladesh. J Freshw Ecol 27: 131-142.

Indarjo A, Salim G, Zein M, Septian D, Bija S. 2020a. The population and mortality characteristics of mangrove crab (Scylla serrata) in the mangrove ecosystem of Tarakan City, Indonesia. Biodiversitas 21 (8): 3856-3866. DOI: 10.13057/biodiv/d210855.

Indarjo A, Salim G, Zein M, Soejarwo PA, Nugraeni CD, Bija S, Pham YTH. 2020b. Characteristics of Von Bertalanffy growth, allometric, condition index and mortality of Periophthalmus barbarus in Mangrove and Bekantan Conservation Area (KKMB), Tarakan, North Kalimantan. Indon J Mar Sci 25 (1): 31-38. DOI: 10.14710/ik.ijms.25.1.31-38.

Indarjo A, Salim G, Amir F, Supriadi S, Soejarwo PA, Nugraeni CD, Prakoso LY, Ambariyanto A, Firdaus M, Ransangan J. 2020c. Growth characteristics layur fish Lepturacanthus savala in Juata Waters, Tarakan, Indonesia. Indon J Mar Sci 25 (3): 127-134. DOI: 10.14710/ik.ijms.25.3.127-134.

Indarjo A, Salim G, Nugraeni CD, Sari IM, Zein M, Prakoso LY, Daengs AGS. 2020d. The growth model composition of giant prawns (Macrobrachium rosenbergii) in Muara Tepian, Nunukan. IOP Conf Ser Earth Environ Sci 564: 012002. DOI:10.1088/17551315/564/1/012002.

Indarjo A, Salim G, Nugraeni CD, Prakoso LY, Soejarwo PA, Rukisah, Pham YTH, Daengs AGS, Hariyadi, Jabarsyah A. 2020e. Analysis model of giant prawns population (Macrobrachium rosenbergii) in estuary edge of Sembakung Waters, Nunukan, Indonesia. Jurnal Ilmiah Perikanan dan Kelautan 12 (2): 236-249. DOI: 10.20473/jipk.v12i2.18829.

Karplus I, Barki A, Israel Y, Cohen S. 1991. Social control of growth in Macrobrachium rosenbergii. II. The "leapfrog" growth pattern. Aquaculture 96: 353-365.

Khasani I. 2008. Upaya peningkatan produktivitas dalam usaha pembesaran udang galah (Macrobrachium rosenbergii de Man). Media Akuakultur 3 (1): 25-30. [Indonesian]

Khairul Adha AR, Nicholas FF, Long SM, Naqiuddin AS, Esa Y. 2016 Short Communication: Fecundity of freshwater prawn (Macrobrachium rosenbergii) in selected rivers of Sarawak, $\begin{array}{lllll}\text { Malaysia. } & \text { Biodiversitas } 17 & \text { (2): 498-502. DOI }\end{array}$ 10.13057/biodiv/d170215.

Kunda M, Dewan S, Uddin MJ, Karim M, Kabir S, Uddin MS. 2008 Length-weight relationship, condition factor and relative condition factor of Macrobrachium rosenbergii in rice fields. Asian Fish Sci 21: 451-456.

Kurup BM, Harikrishnan M, Sureshkumar S. 2000. Length-weight relationship of male morphotypes of Macrobrachium rosenbergii (de Man) as a valid index for differentiating their developmental pathway and growth phases. Indian J Fisheries 47: 283-290.

Lagler KF. 1961. Freshwater Fishery Biology. Second edition. WM. C. Brown Company, Dubuque, Iowa.

Lawal-Are AO, Owolabi AT. 2012. Comparative biology of the prawns Macrobrachium macrobrachion (Herklots) and Macrobrachium vollenhovenii (Herklots) from two interconnecting fresh/brackish water lagoons in South-West Nigeria. J Mar Sci Res Dev 2: 108 DOI: $10.4172 / 2155-9910.1000108$

Lalrinsanga PL, Pillai BR, Patra G, Mohanty S, Naik NK, Sahu S. 2012. Length-weight relationship and condition factor of giant freshwate prawn Macrobrachium rosenbergii (De Man, 1879) based on developmental stages, culture stages and sex. Turkish J Fish Aquat Sci 12: 917-924. DOI: 10.4194/1303-2712-v12419.

Le Cren ED. 1985. The Biology of the Sea Trout. Atlantic Salmon Trust, Pitlochry, UK.

Mantellato FLM, Barbosa LR. 2005. Population structure and Relative growth of freshwater prawn Macrobrachium brasiliense (Decapoda: Palaemonidae) from Sao Paulo Strata, Brasil. Acta Limnol Bras 17 (3): $245-255$

Mejia-Ortiz LM, Alvarez F, Roman R, Pale JAV. 2001. Fecundity and distribution of freshwater prawns of genus Macrobrachium in the Huitzilipan River, Veracruz, Mexico. Crustaceana 74 (1): 69-77.

Ming G, Yue L, Shi D. 2016. Cardiovascular actions and therapeutic potential of tetramethylpyrazine (active component isolated from
Rhizoma Chuanxiong): roles and mechanisms. Biomed Res Intl. 2016: 2430329. DOI: 10.1155/2016/2430329.

Murni I. 2004. Kajian tingkat kematangan gonad udang galah (Macrobrachium rosenbergii de Man) di Muara Sungai Kapuas Pontianak Kalimantan Barat. [Thesis]. Program Pascasarjana, Institut Pertanian Bogor, Bogor. [Indonesian]

Murtidjo BA. 1992. Budidaya Udang Galah Sistem Monokultur. Kanisius, Yogyakarta. [Indonesian]

Nandlal S, Pickering T. 2005. Freshwater Prawns Macrobranchium rosenbergii farming in Pacific Island Countries. Hatchery Operation, Noumea, Secretariat of the Pacific Community, New Caledonia.

New MB. 2002. Farming Freshwater Prawns a Manual for the Culture of the Giant River Prawn Macrobrachium rosenbergii. FAO Fisheries, United Kingdom

New MB. 2005. Freshwater prawn farming: Global status, recent research and a glance at the future. Aquac Res 36 (3): 210-230.

New MB, Kutty MN. 2010. Commercial freshwater prawn farming and enhancement around the world. In: New MB, Valenti WC, Tidwell JH, D’Abramo LR, Kutty MN (eds.). Freshwater Prawns Biology and Farming. Wiley Blackwell Publishing, New York.

Pauly D. 1984. Some Simple Methods for The Assessment of Tropical Fish Stocks. Food and Agriculture Organization of The United Nations. Rome.

Primavera JH, Parado-Estepa FD, Lebata JL. 1998. Morphometric relationship of length and weight of giant tiger prawn Penaeus monodon according to life stage, sex and source. Aquaculture 164: 67-75.

Powell CB. 1983. The Decapods Crustaceans of the Niger Delta. Publication Committee, University of Port Harcourt, Nigeria.

Raswin MM, Hitam MS, Aziz KA. 1981. Study on some biological aspects of Macrobrachium sintangense (de Man). Seminar hasil-hasil Penelitian dan Pengembangan Energi Pedesaan Daerah Lingkar Kampus IPB, Institut Pertanian Bogor, Bogor. [Indonesian]

Rao RM. 1967. Studies on the biology of Macrobrachium rosenbergii (de Man) of the Hooghly Estuary with notes on its fishery. Proc Indian Natl Sci Acad 33 (5): 252-279.

Ricker, W.E. 1975. Computation and interpretation of biological statistics of fish populations. Bulletin of the Fisheries Research Board of Canada, Ottawa.

Salim G. 2015. Analisis pertumbuhan allometri dan indeks kondisi Caesio cunning didapatkan dari hasil tangkapan nelayan Kota Tarakan. Harpodon 8 (1): 35-42. DOI: 10.35334/harpodon.v8i1.125. [Indonesian]

Salim G. 2013. Nilai indeks kondisi dari ikan Siganus javus berdasarkan hasil tangkapan nelayan di Perairan Juata Kota Tarakan. Harpodon 8 (1): 37-42. DOI: 10.35334/harpodon.v6i1.99. [Indonesian]

Sampaio CMS, Valenti WC. 1996. Growth curves for Macrobrachium rosenbergii in semi-intensive culture in Brazil. J World Aquac Soc 27 (3): 353-358. DOI: 10.1111/j.1749-7345.1996.tb00619.x.

Samuel, Aida SN. 2008. Aktivitas Penangkapan dan Distribusi Udang Galah (Macrobrachium rosenbergii) di Daerah Aliran Sungai Kapuas, Kalimantan Barat. Jurnal Penelitian Perikanan Indonesia. DOI: 10.15578/jppi.14.2.2008.181-194

Sofian, Sari YP. 2018. Kajian terhadap pola pertumbuhan udang galah (Macrobrachium rosenbergii) di Sungai Ogan Sumatera Selatan. Jurnal Teknologi Hasil Perikanan 7 (2): 120-123. [Indonesian]

Sparre P, Venema SC. 1999. Introduksi Pengkajian Stok Ikan Tropis. Pusat Penelitian dan Pengembangan Perikanan. Badan Penelitian dan Pengembangan Pertanian, Jakarta. [Indonesian]

Sparre P, Venema SC. 1998 Introduction to Tropical Fish Stock Assessment. Part 1: Manual. FAO Documento Técnico de Pesca, Rome, Italy.

Suwartiningsih N, Trijoko, Handayani NSN. 2017. Variasi morfologis udang galah (Macrobrachium rosenbergii de Man, 1879) hasil inbreeding dan outbreeding populasi Probolinggo dan Mahakam. J Trop Biodiv Biotechnol 2 (2): 57-63. DOI: 10.22146/jtbb.29676. [Indonesian]

Sukarli. 2017. Udang galah paling mahal di pasaran Banjarmasin. https://kalsel.antaranews.com/berita/47583/udang-galah-palingmahal-di-pasaran-banjarmasin. [Indonesian]

Ukagwu JI, Deekae S. 2016. Sex population structure of Macrobrachium felicinum and Macrobrachium vollenhovenii in the Akor river, Ibere Ikwuano, Abia State. Intl J Aquac Aquat Stud 4 (4): 19-23.

Waluyo E, Kusuma B, Yufidasari HS. 2018. Implementation of food security decree on fisheries product in indonesia: case in dangerous 
food additives application. ECSOFiM (Economic and Social of Fisheries and Marine) 5 (2),:215-220

Wang JK. 1985. Weight and width relationship of freshwater prawn (Macrobrachium rosenbergii). Aquac Eng 4 (1): 21-32. DOI: 10.1016/0144-8609(85)90003-2.

Wootton RJ. 1992. Fish Ecology. Chapman \& Hall, London. 212 pp.
Wowor D, Ng PKL. 2007. The giant freshwater prawn of the Macrobrachium rosenbergii group (Crustacea; Decapoda: Caridea; Palaemonidae). Raffles Bull Zool 55 (2): 321-336.

Yudiati E, Fauziah AT, Irwani I, Setyawan A, Insafitri I. 2020. Growth analysis, mortality and exploitation level of mud crab Scylla serrata, Forskål 1775, (Malacostraca: Portunidae) in Mangkang Wetan waters, Semarang, Central Java, Indonesia. Jurnal Kelautan Tropis 23 (1): 136-144. 